Article

\title{
Hepatoprotection of Mentha aquatica L., Lavandula dentata L. and Leonurus cardiaca $\mathrm{L}$.
}

\author{
Olívia R. Pereira $^{1} \mathbb{D}$, Rocio I. R. Macias ${ }^{2} \mathbb{D}$, Maria R. M. Domingues ${ }^{3,4} \mathbb{D}$, Jose J. G. Marin ${ }^{2}(\mathbb{D}$ and \\ Susana M. Cardoso ${ }^{3, * \mathbb{D}}$ \\ 1 Centro de Investigação de Montanha (CIMO), Instituto Politécnico de Bragança, Campus de Santa Apolónia, \\ 5300-253 Bragança, Portugal \\ 2 Laboratory of Experimental Hepatology and Drug Targeting, IBSAL, CIBERehd, University of Salamanca, \\ 37007 Salamanca, Spain \\ 3 Department of Chemistry \& QOPNA, University of Aveiro, 3810-193 Aveiro, Portugal \\ 4 Department of Chemistry \& CESAM\&ECOMARE, University of Aveiro, 3810-193 Aveiro, Portugal \\ * Correspondence: susanacardoso@ua.pt; Tel.: +351-234-370-360; Fax: +351-234-370-084
}

Received: 24 June 2019; Accepted: 30 July 2019; Published: 2 August 2019

\begin{abstract}
The phenolic composition of hydroethanolic extracts of Mentha aquatica L., Lavandula dentata L. and Leonurus cardiaca L., obtained from plants grown under organic cultivation, was determined and their hepatoprotective effects were investigated in vitro. L. cardiaca extract was rich in phenylethenoid glycosides, especially lavandolifolioside $(254 \pm 36 \mu \mathrm{g} / \mathrm{mg})$, whereas rosmarinic acid and eriodictyol-O-rutinoside were the major phenolic compounds of L. dentata and M. aquatica extracts, accounting for $68 \pm 7 \mu \mathrm{g} / \mathrm{mg}$ and $145 \pm 22 \mu \mathrm{g} / \mathrm{mg}$, respectively. These differential phenolic components presumably account for their dissimilar antioxidant properties. While L. cardiaca extract showed moderate biological effects, M. aquatica extract displayed high antioxidant activity in chemical models, and that of L. dentata was effective in counteracting potassium dichromate-induced ROS generation in human hepatocarcinoma cells. Moreover, M. aquatica extract $(50 \mu \mathrm{g} / \mathrm{mL})$ and its mixture (50\%/50\%) with L. dentata extract displayed an effective cytoprotective effect.
\end{abstract}

Keywords: Mentha; Lavandula; Leonurus; liver diseases; HepG2 cells; antioxidant; phenolic compounds; UHPLC-DAD-ESI-MS ${ }^{n}$

\section{Introduction}

Liver diseases comprise a large number of conditions, either caused by genetic modifications or, more frequently, by viruses, alcohol abuse, toxins or drugs. Liver injury induced by toxins and drugs, haemochromatosis, hepatitis, cirrhosis, and hepatocellular carcinoma are among liver conditions with poor response to available treatments [1].

In recent decades, phytochemicals from plants have been proposed as health supplements acting as preventive agents or for treatment in patients with liver disorders [2]. In this context, polyphenols represent one of the groups with most interest [3] due to their claimed antioxidant and anti-inflammatory properties $[4,5]$. In fact, oxidative and inflammatory processes are recognized as critical in the pathogenesis and progression of liver conditions [5].

Lamiaceae family is one of the most applied in traditional medicine, as it encloses many plant species which are claimed to exert important pharmacological activities, including antioxidant, antiproliferative, anti-tumoral, anti-inflammatory, antimicrobial, analgesic, and neuroprotective, among others [4]. Mentha aquatica L., Lavandula dentata L. and Leonurus cardiaca L. are three of such species, being used for centuries in traditional medicine for several purposes. In particular, the first is frequently applied in the treatment of external inflammation and in inflammation-related diseases, such 
as rheumatism, although it is also used as a vermifuge, in the treatment against colds and respiratory problems; to counteract mental illnesses or disorders of the central nervous system; and to attenuate menstruation problems, as a stimulant and as an emetic and astringent agent [6-8]. In turn, French lavender, or Lavandula dentata, has been used as an antidiabetic agent [9] and in cold and renal colic treatments [10], while Leonurus cardiaca (motherwort) usages include sedative, uterotonic, diuretic, cardiotonic, and hypotensive, as well as bronchial asthma protection [11].

At the scientific level, the bioactive properties of M. aquatica, L. dentata and L. cardiaca have been mostly associated with their phenolic constituents, which are generally major components in extracts obtained with polar solvents (e.g., water, ethanol, methanol, water/alcohol or water/acetone mixtures). The antioxidant capacity of polar extracts from these three plants has been previously tested through chemical antiradical assays [12-20]. Besides, neuroprotective effects of methanolic and aqueous extracts of $M$. aquatica aerial parts were shown to counteract oxidative stress in an $\mathrm{H}_{2} \mathrm{O}_{2}$-induced toxicity model in PC12 cells, along with the high ability to inhibit monoamine oxidase (MAO) and a moderate affinity towards $\mathrm{GABA}_{\mathrm{A}}$ receptor $[6,21]$. Besides, hydroethanolic extracts of this plant were reported to exhibit promising antiproliferative and anti-inflammatory activities, as demonstrated in MCF-7 human breast cancer cells [22] and in an in-vivo mice model [7], respectively.

In contrast to $M$. aquatica, $L$. dentata extracts have been scarcely studied. Still, promising antiproliferative and apoptotic activities were demonstrated in MCF-7 cells [18]. Moreover, the anti-inflammatory effects of hydromethanolic extracts from this plant were evidenced using bone marrow-derived macrophages and murine epithelial cell lines, as well as in mice [18]. Notably, the anti-inflammatory activity of $L$. cardiaca was also suggested by Flemmig et al., when demonstrating the high lactoperoxidase activity of 70\% ethanol extracts [23]. Besides, high in-vitro immunomodulatory potential was reported for an hydroacetonic extract in HUVECs cells due to their effects on viability, apoptosis, NO• production, cytotoxicity, and platelet-activating factor secretion. This extract has also shown to be capable of reducing platelet aggregation [20].

Taking into account the claimed antioxidant and anti-inflammatory potential of M. aquatica, L. dentata and L. cardiaca polar extracts, we decided to evaluate the hepatoprotective activities of hydroethanolic extracts obtained from these three plants and investigate the relationship between their antioxidant properties and their specific phenolic composition. Interestingly, in contrast to previous studies on these extracts that were mostly obtained from wild plants, the botanical samples herein used have been cultivated under an organic regime, which is currently pointed as one important market strategy [24]. In fact, organic cultivation is recognized as a sustainable agricultural system, and medicinal and aromatic products produced under this system are readily accepted in global markets and command higher prices than those grown with chemical inputs [7], also claiming to contain higher amounts of specific phytochemicals, namely phenolic compounds [25,26].

\section{Materials and Methods}

\subsection{Chemicals}

BHA (butylated hydroxyanisole) and $\mathrm{DPPH}^{\bullet}$ (2,2-diphenyl-2-picrylhydrazyl radical) were obtained from Sigma Chemical Co (St Louis, MO, USA). Porcine trypsin was purchased from Roche (Barcelona, Spain). Tripan blue, dimetilsulfoxide (DMSO), "Minimum Essential Medium Eagle (MEM)" and RPMI-1640 culture media, mix of antibiotics and antimycotic, sodium piruvate, sodium bicarbonate, 3-(4,5-dimethylthiazol-2-yl)-2,5-diphenyltetrazolium bromide (MTT), dichlorofluorescein diacetate, cisplatin, and potassium dichromate were purchased from Sigma-Aldrich (Madrid, Spain) and fetal bovine serum (FBS) was obtained from T.D.I. (Madrid, Spain). The phenolic standards eriodictyol-7-O-glucoside, naringenin-7-O-glucoside, luteolin-7-O-glucoside, quercetin-7-O-rutinoside, rosmarinic acid, and verbascoside were obtained from Extrasynthese (Genay Cedex, France). Ascorbic acid, formic acid and ethanol were purchased from Panreac (Barcelona). $n$-Hexane, methanol and acetonitrile, all with HPLC purity, were purchased from Lab-Scan (Lisbon, Portugal). 


\subsection{Plant Material and Obtention of Phenolic-Rich Extracts}

Aerial parts (leaves and stems) of M. aquatica and L. cardiaca and flowers of L. dentata were purchased from Ervital (Mezio-Castro Daire, Portugal, GPS coordinates 40.976351, -7.903492), a pioneer company in Portugal in organic farming, specialized in the production and commercialization of aromatic and medicinal plants using an organic regime growth in fields of Serra do Montemuro, located in Montemuro region at about $1000 \mathrm{~m}$ of altitude. The plants have been cultivated under the general conditions described by Afonso et al. [27]. After collection, the aerial parts were dried in a ventilated incubator at 20 to $35^{\circ} \mathrm{C}$ for 3 to 5 days.

The extracts were prepared after defatting the plant powder with $n$-hexane, (1:30), following the general procedure described by Pereira et al. [28] i.e., the defatted residue was extracted six times with $150 \mathrm{~mL}$ of $80 \%$ ethanolic solution $(v / v)$ at room temperature for $1 \mathrm{~h}$.

The resulting dispersions were combined, filtrated through a G3 sintered plate filter, concentrated, and then treated in order to obtain phenolic-rich extracts [28]. In detail, approximately $0.4 \mathrm{~g}$ of each ethanolic extract was dissolved in $15 \mathrm{~mL}$ of water and eluted in three Strata SPE C18-E cartridges (2 g, Waters, Milford, MA, USA). The cartridges were then washed three times with $30 \mathrm{~mL}$ of water, and the phenolic compounds were recovered by elution with $20 \mathrm{~mL}$ of methanol. The resulting extracts were concentrated in a rotary evaporator, frozen at $-20^{\circ} \mathrm{C}$, freeze-dried, and kept under vacuum in a desiccator in the dark.

\subsection{Evaluation of Radical Scavenging and Inhibition of 5-Lipoxygenase Activities}

\subsubsection{Reducing Power, $\mathrm{DPPH}^{\bullet}$ Scavenging Activity}

The ability of M. aquatica $(0.025-0.25 \mathrm{mg} / \mathrm{mL})$, L. dentata $(0.05-0.25 \mathrm{mg} / \mathrm{mL})$ and L. cardiaca $(0.05-0.25 \mathrm{mg} / \mathrm{mL})$ ethanolic extracts in reducing iron (III) was assessed by the method described by Catarino et al. [29]. In more detail, the different concentrations of each extract were mixed with $2.5 \mathrm{~mL}$ of $0.2 \mathrm{M}$ phosphate buffer $(\mathrm{pH} 6.6)$ and $2.5 \mathrm{~mL}$ of $1 \%$ potassium hexacyanoferrate $\left[\mathrm{K}_{3} \mathrm{Fe}(\mathrm{CN})_{6}\right]$ aqueous solutions. After $20 \mathrm{~min}$ of incubation at $50{ }^{\circ} \mathrm{C}, 2.5 \mathrm{~mL}$ of $4 \%$ trichloroacetic acid was added followed by vigorous stirring. After that, $2.5 \mathrm{~mL}$ of each solution was transferred to new vials where $2.5 \mathrm{~mL}$ of deionized water and $0.5 \mathrm{~mL}$ of $0.1 \%$ of iron chloride $\left(\mathrm{FeCl}_{3}\right)$ were added, and the absorbance was then measured at $700 \mathrm{~nm}$. A linear regression analysis was carried out by plotting the mean absorbance against the concentrations, and the $\mathrm{EC}_{50}$ value was determined considering the extract concentration that provides 0.5 of absorbance. BHA was used as a reference compound.

The capacity of M. aquatica $(0.025-0.25 \mathrm{mg} / \mathrm{mL})$, L. dentata $(0.05-0.5 \mathrm{mg} / \mathrm{mL})$ and L. cardiaca $(0.05-0.5 \mathrm{mg} / \mathrm{mL})$ to scavenge DPPH radical was performed according to the procedure previously described [30]. Briefly, $0.1 \mathrm{~mL}$ of different concentrations of the extracts was prepared and added to $1.9 \mathrm{~mL}$ of a methanolic solution of $\mathrm{DPPH}^{\bullet}$, followed by vigorous stirring. After $30 \mathrm{~min}$ of incubation in the dark, the absorbance of the mixtures was measured in a spectrophotometer at $517 \mathrm{~nm}$, against a blank (absence of $\mathrm{DPPH}^{\bullet}$ ). The radical scavenging activity of each ethanolic extract was calculated as the percentage of $\mathrm{DPPH}^{\bullet}$ discoloration: \% $\mathrm{DPPH}^{\bullet}$ scavenging $=\left(\mathrm{A}_{\mathrm{c}(0)}-\mathrm{A}_{\mathrm{e}(\mathrm{t})}\right) / \mathrm{A}_{\mathrm{c}(0)} \times 100$, where: $\mathrm{A}_{\mathrm{c}(0)}=$ Absorbance of the control at $t=0 \mathrm{~min} ; \mathrm{A}_{\mathrm{e}(\mathrm{t})}=$ Absorbance of the extract at $t=30 \mathrm{~min}$. Based on the graphic values of the percentage of DPPH radical inhibition vs. extract concentration, the $\mathrm{EC}_{50}$ (concentration of the extract able to inhibit the $50 \%$ of the DPPH) of each extract was calculated. Ascorbic acid was used as a reference.

\subsection{2. $\mathrm{NO}^{\bullet}$ Scavenging Test}

The ability of extracts in scavenging $\mathrm{NO}^{\bullet}$ followed the methodology previously reported by Afonso et al. [31]. In brief, $100 \mu \mathrm{L}$ of sodium nitroprusside (3.33 mM) in PBS $100 \mathrm{mM}(\mathrm{pH}=7.4)$ were added with $100 \mu \mathrm{L}$ of the different sample concentrations $(0.02-1 \mathrm{mg} / \mathrm{mL})$ of each extract and incubated for $10 \mathrm{~min}$ at room temperature under light irradiation. Sodium nitroprusside is known to decompose in aqueous solution at physiological $\mathrm{pH}$ (7.2), producing $\mathrm{NO}^{\bullet}$, and this, in turn, interacts with molecular 
oxygen, producing $\mathrm{NO}_{2}{ }^{-}$, which in the presence of Griess reagent $(100 \mu \mathrm{L}, 1 \%$ of sulfanilamide and $0.1 \%$ of naphthylethylenediamine dihydrochloride in $2.5 \%$ of phosphoric acid) produces a purple azo dye. The measurement of the absorbance was determined spectrophotometrically at $562 \mathrm{~nm}$. The $\mathrm{EC}_{50}$ value for the $\mathrm{NO}^{\bullet}$ scavenging activity was determined by plotting the percentage of inhibition of nitrite generation in the presence of the plant extracts against the tested concentrations. Ascorbic acid was used as the reference compound.

\subsubsection{Inhibition of 5-Lipoxygenase (5-LOX)}

The 5-LOX inhibitory assay was performed in a quartz 96-well plate according to the procedure of Afonso et al. [31], with some modifications. For that, $20 \mu \mathrm{L}$ of the extract sample solutions $(0.1-1.0 \mathrm{mg} / \mathrm{mL}$ for M. aquatica, $0.2-3.0 \mathrm{mg} / \mathrm{mL}$ for L. dentata and $0.2-3.0 \mathrm{mg} / \mathrm{mL}$ for L. cardiaca) and $20 \mu \mathrm{L}$ of the 5-LOX work solution were added to each well and incubated at $37^{\circ} \mathrm{C}$ in the plate reader for $10 \mathrm{~min}$. The reaction was then initiated by the addition of $40 \mu \mathrm{L}$ of pre-heated linoleic acid $(500 \mu \mathrm{M})$ and the formation of $(9 Z, 11 E)$-(13S)-13-hydroperoxyoctadeca-9,11-dienoate was followed for $20 \mathrm{~min}$ taking measurements every minute at $234 \mathrm{~nm}$. The reaction rate at each inhibitor concentration was calculated by determining the slope of the experimental values and the percentage of inhibition by the following formula.

$$
\%_{\text {inhibition }}=\frac{v_{0}-v_{[\text {inhibitor }]}}{v_{0}} \times 100
$$

where $v_{0}$ corresponds to the reaction rate of control and $v_{[i n h i b i t o r]}$ to the reaction rate of the extract. $\mathrm{EC}_{50}$ corresponds to the concentration of the tested extract able to inhibit the hydrolysis of the substrate (linoleic acid) by about $50 \%\left(\mathrm{EC}_{50}\right)$. Ascorbic acid was used as the reference.

\subsection{Evaluation of Biological Activity in Cellular Assays}

\subsubsection{Cell Culture and Treatments}

The general cell culture procedures and those of MTT and ROS experiments followed the procedures previously described by Pereira et al. [30]. The hydroethanolic extracts of M. aquatica, $L$. dentata or L. cardiaca (final concentrations of 1-200 $\mu \mathrm{g} / \mathrm{mL}$ ) and/or potassium dichromate $\left(\mathrm{K}_{2} \mathrm{Cr}_{2} \mathrm{O}_{7}\right)$ (final concentrations of 1.5, 5, 25 or $500 \mu \mathrm{M}$ ) were dissolved in the culture medium. Twenty-four hours after seeding, the cells' culture medium was replaced by fresh culture medium containing the treatment agents and the cells were maintained in culture, for $6 \mathrm{~h}$ or $72 \mathrm{~h}$ (in the MTT assay, to measure acute and long-term toxicity, respectively) or $48 \mathrm{~h}$ (intracellular ROS).

\subsubsection{MTT Assay}

The viability of HepG2 cells was estimated by the formazan formation from the tetrazolium salt by living cells, as previously described [30,32]. Cell viability was calculated as the percentage of living cells compared to untreated (control) cells. Cisplatin $(0.3$ to $30 \mu \mathrm{g} / \mathrm{mL})$ was used as a positive control.

\subsubsection{Intracellular ROS Production}

ROS production was analyzed by flow cytometry following the procedure described by Pereira et al. [30]. After $48 \mathrm{~h}$ incubation of HepG2 cells with the hydroethanolic extracts and/or potassium dichromate, the medium was replaced by RPMI culture medium containing $5 \mu \mathrm{g} / \mathrm{mL}$ of the probe 2,7-dichlorofluorescein diacetate (DCFH-DA) for $30 \mathrm{~min}$, and then cells were trypsinized and resuspended in FBS free-medium. ROS generation was measured and analyzed in a cytometer FACSort flow cytometer (BD Biosciences, San Jose, CA, USA) with CellQuest software (BD Biosciences). The values were normalized to the percentage of ROS formation by the untreated cells. 


\subsection{Analysis of the Phenolic Compounds}

The analysis of phenolic compounds was performed by liquid chromatography under the general conditions previously described by Catarino et al. [29]. Gradient elution was carried out with a mixture of $0.1 \%(v / v)$ of formic acid in water (solvent A) and acetonitrile (solvent B), starting from 10 to $20 \%$ of solvent B over $6 \mathrm{~min}$, from 20 to $25 \%$ of solvent B over $12 \mathrm{~min}$, from 25 to $34 \%$ over $30 \mathrm{~min}$, increasing to $100 \%$ at $37 \mathrm{~min}$ maintaining for $3 \mathrm{~min}$, followed by the return to the initial conditions at $40 \mathrm{~min}$. The identification of phenolic compounds was corroborated by MS analysis using a Thermo LTQ XL (Thermo Scientific, USA) ion trap MS apparatus equipped with an ESI source, operating in negative mode, under the same conditions as previously described [28]. Additionally, the quantification of the majority of the compounds in three plant extracts was performed by peak integration using the external standard method, with the exact or structurally-related standard compounds. Considering the nature of the phenolic compounds, eriodictyol-7-O-glucoside was used to quantify eriodictyol-O-rutinoside and hesperetin-7-O-rutinoside; naringenin-7-O-glucoside was used to quantify naringenin-7-O-rutinoside; luteolin-7-O-glucoside was used to quantify luteolin glycosides (peaks 6, 10 and 12); Flavonols (peaks 3,9 and 11) were quantified with quercetin-7-O-rutinoside; Caffeic acid derivatives (peaks 1 and 16) were quantified with rosmarinic acid; while verbascoside was used to quantified the phenylethanoid glycosides (peaks 5, 7, 14 and 15). The linearity of the calibration curves, the regression coefficient $\left(R^{2}\right)$ and the detection and quantification limits (LOD and LOQ, respectively) are represented in Table S1.

\subsection{Statistical Analysis}

All statistical analyses were performed with GraphPad Prism 6 statistical software (GraphPad, San Diego, CA, USA). Data were expressed as mean \pm S.D. or as mean \pm S.E.M. of three to four independent experiments performed at least in triplicate. The comparison between groups was performed by one-way ANOVA, followed by Tukey's test. Unpaired Student's $t$-test was used for comparison between two groups. Correlation analyses were performed using a two-tailed Pearson's correlation test. A difference was considered statistically significant when $p<0.05$. For cellular assays, ${ }^{*} p<0.05$; ${ }^{* * *} p<0.001$ when compared to cells exposed to potassium dichromate in the absence of extracts; \#\#\# $p<0.01$; \#\#\# $p<0.0001$ when compared to untreated cells.

\section{Results and Discussion}

\subsection{Antioxidant and Anti-Inflammatory Properties (in Chemical Models)}

The hydroethanolic extracts of M. aquatica, L. dentata and L. cardiaca exhibited promising antioxidant potential, as evaluated by $\mathrm{DPPH}^{\bullet}$ and reducing power assays, with potencies order of M. aquatica > L. dentata $>$ L. cardiaca and $\mathrm{EC}_{50}$ values ranging from $8.1 \pm 1.3$ to $18.3 \pm 1.5$ (corresponding to about three to seven times higher than that of ascorbic acid) and from $51.9 \pm 12.6$ to $94.7 \pm 12.1$ (about two to three times higher than that of BHA, used as the standard) (Table 1), respectively. In general, the herein registered $\mathrm{EC}_{50}$ values for $\mathrm{DPPH}^{\bullet}$ are promising when compared to previous literature data for methanol, hydromethanolic or aqueous (at $50^{\circ} \mathrm{C}$ ) extracts of $M$. aquatica $(27-50.0 \mu \mathrm{g} / \mathrm{mL}$ corresponding to 4-15 times that of ascorbic acid) [20,32], of L. dentata (48.7-71.1 $\mu \mathrm{g} / \mathrm{mL}$ equivalent to 24-fold that of ascorbic acid) $[17,18]$ and L. cardiaca $(12-144 \mu \mathrm{g} / \mathrm{mL})[33,34]$. 
Table 1. Yield of extraction (\%), antioxidant and anti-inflammatory activities $\left(\mathrm{EC}_{50}, \mu \mathrm{g} / \mathrm{mL}\right)$ of M. aquatica, L. dentata and L. cardiaca extracts.

\begin{tabular}{cccccc}
\hline Sample & $\begin{array}{c}\text { Yield } \\
(\mathbf{\%})\end{array}$ & $\begin{array}{c}\text { DPPH Scavenging } \\
(\mu \mathrm{g} / \mathrm{mL})\end{array}$ & $\begin{array}{c}\text { Reducing Power } \\
(\mu \mathrm{g} / \mathrm{mL})\end{array}$ & $\begin{array}{c}\mathbf{N O}^{\bullet} \text { Scavenging } \\
(\boldsymbol{\mu g} / \mathbf{m L})\end{array}$ & $\begin{array}{c}\text { 5-LOX Inhibition } \\
(\mu \mathrm{g} / \mathrm{mL})\end{array}$ \\
\hline M. aquatica & 11.3 & $8.1 \pm 1.3^{\mathrm{a}}$ & $51.9 \pm 12.6^{\mathrm{a}}$ & $217.0 \pm 19.0^{\mathrm{a}}$ & $174.5^{\mathrm{a}} \pm 30.5^{\mathrm{a}}$ \\
L. dentata & 3.2 & $11.6^{\mathrm{a}} \pm 1.1^{\mathrm{b}}$ & $78.9 \pm 2.6^{\mathrm{b}}$ & $879.3 \pm 192.8^{\mathrm{b}}$ & $237.9 \pm 15.2^{\mathrm{b}}$ \\
L. cardiaca & 3.7 & $18.3^{\mathrm{b}} \pm 1.5^{\mathrm{c}}$ & $94.7 \pm 12.1^{\mathrm{b}}$ & $>1000$ & $>1000$ \\
AA & - & $2.5 \pm 0.4^{\mathrm{d}}$ & - & $92.0 \pm 7.3^{\mathrm{c}}$ & $7.8^{\mathrm{c}} \pm 1.0^{\mathrm{c}}$ \\
BHA & - & - & $27.1 \pm 1.2^{\mathrm{c}}$ & - & - \\
\hline
\end{tabular}

Mean values \pm SD. Statistical analysis was performed by one-way ANOVA, followed by a Tukey's test. In each column, different letters $(\mathrm{a}-\mathrm{d})$ mean significant differences $(p<0.05)$; RP: Reducing Power; AA: Ascorbic acid; BHA: Butylated hydroxyanisole; 5-LOX: 5-lipoxygenase.

The ability of $M$. aquatica, L. dentata and L. cardiaca hydroethanolic extracts to counteract inflammatory events was evaluated by $\mathrm{NO}^{\bullet}$ scavenging and 5-LOX inhibitory methods. $\mathrm{NO}^{\bullet}$ is a chemical mediator generated in biological tissues, while 5-LOX acts as a key enzyme in leukotrienes biosynthesis. These molecules are potent mediators involved in various physiological processes and are related to inflammatory conditions. As shown in Table 1, relevant activity was only observed for the $M$. aquatica extract, particularly regarding its ability to scavenge $\mathrm{NO}^{\bullet}$, which corresponded to about a quarter of that of ascorbic acid $\left(\mathrm{EC}_{50}\right.$ of $217.0 \pm 19.0$ and $92.0 \pm 7.3 \mu \mathrm{g} / \mathrm{mL}$, respectively). Please note that the in-vivo anti-inflammatory effect has been previously described for M. aquatica [7] and L. dentata hydroalcoholic extracts [18], although authors did not elucidate the molecular mechanisms behind their effects. Hence, our results seem to suggest that, while NO• scavenging and LOX inhibition might be partially involved in the inflammatory protection of $M$. aquatica extract, they do not play a role in the case of L. dentata and L. cardiaca extracts.

\subsection{Hepatoprotective Activities in HepG2 Cells}

The human hepatocarcinoma cell line HepG2, which retains many specialized functions of normal human hepatocytes, was used because this is a common model to screen possible protective effects of compounds/extracts in liver cells. The MTT assay performed after $72 \mathrm{~h}$ exposure of these cells to $M$. aquatica, L. dentata and L. cardiaca hydroethanolic extracts $(1-200 \mu \mathrm{g} / \mathrm{mL})$ allowed to conclude that the latter was the one that least affected their metabolic activity (Figure 1). In fact, while this extract only caused a negative impact on the viability of HepG2 cells at concentrations $>100 \mu \mathrm{g} / \mathrm{mL}$, the toxic limit for M. aquatica and L. dentata was lower $(50 \mu \mathrm{g} / \mathrm{mL})$.

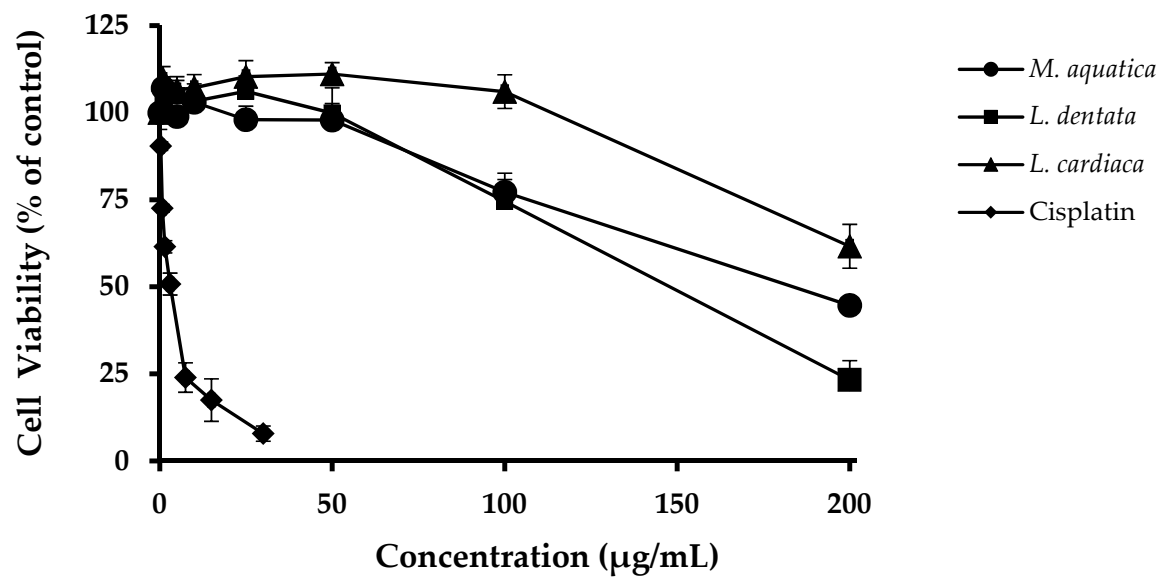

Figure 1. Viability of HepG2 cells exposed for $72 \mathrm{~h}$ to a concentration range of cisplatin ( 0.3 to $30 \mu \mathrm{g} / \mathrm{mL}$ ), used here as a toxic positive control, or of hydroethanolic extracts ( 1 to $200 \mu \mathrm{g} / \mathrm{mL}$ ) obtained from $M$. aquatica, L. dentata and L. cardiaca. Values are means \pm SD of the percentage of cell viability with respect to control untreated cells. 
Considering the above results, the comparison of the potency of the three plant extracts in protecting HepG2 from ROS generation and cell death was further investigated at $50 \mu \mathrm{g} / \mathrm{mL}$ [29]. In this and previous studies, we have used potassium dichromate $\left(\mathrm{K}_{2} \mathrm{Cr}_{2} \mathrm{O}_{7}\right)$ as a model aggressive agent because of its ability to generate oxidative stress and interact with intracellular macromolecules causing DNA damage [35]. $\mathrm{K}_{2} \mathrm{Cr}_{2} \mathrm{O}_{7}$ affects HepG2 cells through multiple mechanisms, which overall cause a massive increase of ROS and ultimately lead to cell death through apoptosis and necrosis. These effects are dependent on the time and levels of exposure to the toxic substance [5,30,36,37].

As shown in Figure 2, the treatment of HepG2 with $\mathrm{K}_{2} \mathrm{Cr}_{2} \mathrm{O}_{7}$ at $5 \mu \mathrm{M}$ and $25 \mu \mathrm{M}$ deregulated ROS production versus cellular antioxidant balance, resulting in increased ROS intracellular levels by over 1.7-fold and 2.4-fold, respectively. These effects could be counteracted by the presence of the plant extracts, particularly from M. aquatica and L. dentata origin. Of note, regardless, being less active than $M$. aquatica extract in $\mathrm{DPPH}^{\bullet}$ and reducing power assays, L. dentata extract showed the highest effectiveness in attenuating ROS formation in HepG2 cells. Thus, a significant decrease in the rate of $\mathrm{K}_{2} \mathrm{Cr}_{2} \mathrm{O}_{7}$ induced ROS production ( $23 \%$ and $31 \%$, at $5 \mu \mathrm{M}$ and $25 \mu \mathrm{M}$, respectively), as well as under non-stimulated conditions of ROS production (36\%) was observed. In contrast, the protective effects of $M$. aquatica were only significant for the most-toxic conditions, i.e., during incubation with $25 \mu \mathrm{M} \mathrm{K}_{2} \mathrm{Cr}_{2} \mathrm{O}_{7}$.

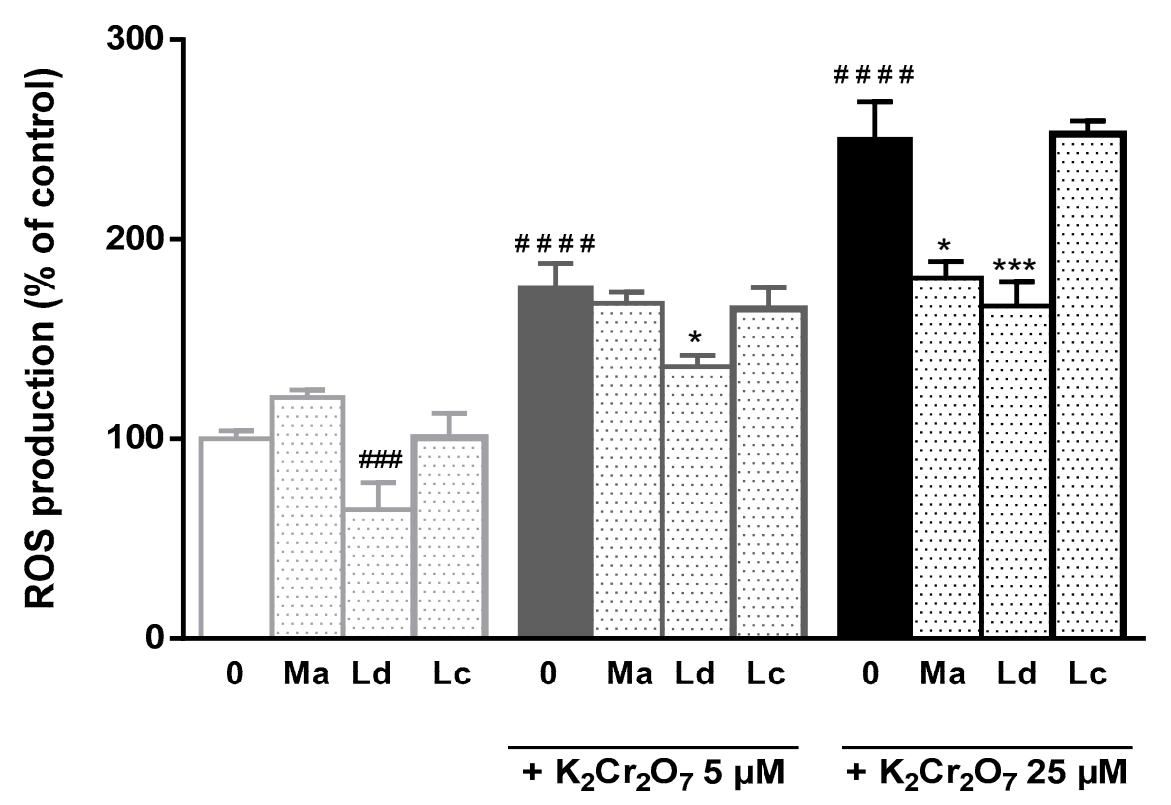

Figure 2. Effect of M. aquatica, L. dentata and L. cardiaca hydroethanolic extracts (at $50 \mu \mathrm{g} / \mathrm{mL})$ in ROS production in HepG2 cells in the absence or presence of 5 or $25 \mu \mathrm{M}$ of potassium dichromate. Values are expressed as means \pm S.D. of percentage of ROS production with respect to the control (untreated cells). $\mathrm{K}_{2} \mathrm{Cr}_{2} \mathrm{O}_{7}$, potassium dichromate; Ma, M. aquatica extract; Ld, L. dentata extract; Lc, L. cardiaca extract.

The possible protection activity of extracts towards loss of cell viability induced by $\mathrm{K}_{2} \mathrm{Cr}_{2} \mathrm{O}_{7}$ was also tested in two cytotoxic models, namely $500 \mu \mathrm{M} \mathrm{K}_{2} \mathrm{Cr}_{2} \mathrm{O}_{7}$ for $6 \mathrm{~h}$ (acute toxicity) and $1.5 \mu \mathrm{M}$ $\mathrm{K}_{2} \mathrm{Cr}_{2} \mathrm{O}_{7}$ for $72 \mathrm{~h}$ (long-term toxicity) [38]. Overall, the exposure to the toxic agent caused a decrease in cell viability of about $45 \%$ and $30 \%$, respectively (Figure 3). These results showed that none of the extracts could prevent the loss of viability in cells cultured under a strong toxic treatment but still, both M. aquatica extract $(50 \mu \mathrm{g} / \mathrm{mL})$ and M. aquatica/L. dentata mixture $(25 \mu \mathrm{g} / \mathrm{mL}$ each) were able to protect the cells from a mild toxic insult. Our results suggest that $M$. aquatica does effectively reduce the levels of ROS in liver cells. No clear inhibition of ROS production was observed when this was induced by low concentrations of $\mathrm{K}_{2} \mathrm{Cr}_{2} \mathrm{O}_{7}$, nevertheless, at higher concentrations and hence higher levels of oxidative stress, a significant antioxidant effect of $M$. aquatica extract was seen (Figure 2). Since M. aquatica and $L$. dentata were able to reduce $\mathrm{ROS}$ production induced by $\mathrm{K}_{2} \mathrm{Cr}_{2} \mathrm{O}_{7}$, but only M. aquatica 
partially prevented cell death induced by a mild dose of the toxic compound over the long term, this suggests that the cytoprotective effect of $M$. aquatica could be mediated through ROS-dependent scavenging action; however, this must be confirmed by other assays which evidence the mechanisms. In contrast, the antioxidant protection conferred by $L$. dentata was not translated to an evident defense against the $\mathrm{K}_{2} \mathrm{Cr}_{2} \mathrm{O}_{7}$-induced long-term toxicity effect.

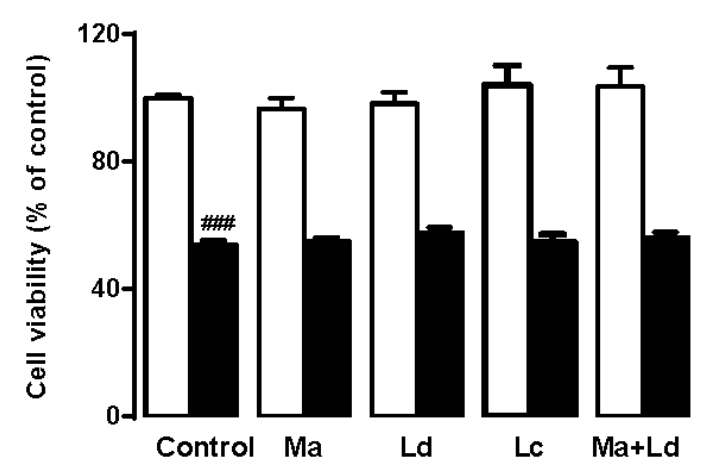

(a)

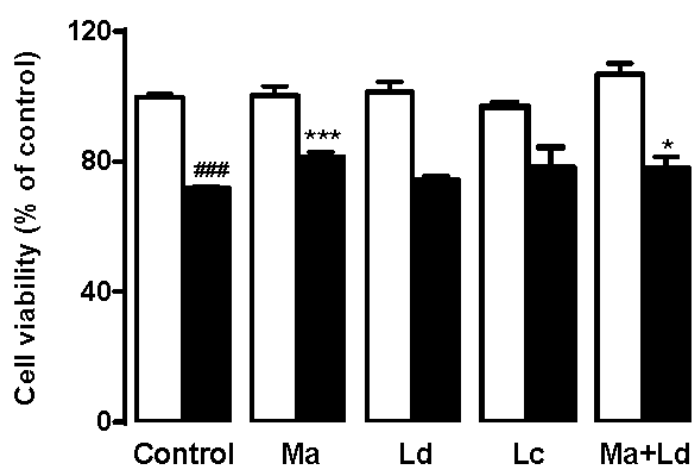

(b)

Figure 3. Effect of M. aquatica, L. dentata and L. cardiaca hydroethanolic extracts on HepG2 viability incubated with $500 \mu \mathrm{M}$ or $1.5 \mu \mathrm{M} \mathrm{K}{ }_{2} \mathrm{Cr}_{2} \mathrm{O}_{7}$ for $6 \mathrm{~h}(\mathbf{a})$ or $72 \mathrm{~h}(\mathbf{b})$, respectively, in absence (white bars) or in presence (black bars) of $\mathrm{K}_{2} \mathrm{Cr}_{2} \mathrm{O}_{7}$. Values are expressed as means \pm S.D. of percentage of cell viability with respect to control (untreated cells). Ma, M. aquatica extract; Ld, L. dentata extract; Lc, L. cardiaca extract.

\subsection{Phenolic Characterization of M. aquatica, L. dentata and L. cardiaca Hydroethanolic Extracts}

Considering that the bioactive properties of M. aquatica, L. dentata and L. cardiaca are mainly claimed to be associated with their phenolic constituents [7,18,34], the phenolic composition of the three extracts was herein evaluated. Overall, the total amounts of phenolic compounds in the extracts followed the sequence order of $L$. cardiaca $>M$. aquatica $>$ L. dentata, with values of $500 \pm 49,307 \pm 29$ and $94 \pm 4 \mu \mathrm{g} / \mathrm{mg}$, respectively (data not shown). Moreover, their phenolic profiles were quite different to each other (Figure S1 and Table 2).

Thus, while the extract from M. aquatica origin was mainly composed of flavanones, such as eriodictyol, naringenin and hesperitin glycosides, L. dentata extract was rich in rosmarinic acid, reaching up to $72 \%$ of the total quantified phenolic compounds. In turn, phenylethanoid glycosides comprised the most prevalent phenolics in L. cardiaca extracts, specially lavandulifolioside and verbascoside (254 \pm 36 and $137 \pm 20 \mu \mathrm{g} / \mathrm{mg}$ extract, respectively). In general, the chemical composition of the extract analyzed in the present study agreed with previous reported data regarding these three plants $[18,23,39,40]$. Nevertheless, this is the first time that leucoseptoside A (MW 638, 31.5 $\pm 4.6 \mu \mathrm{g} / \mathrm{mg}$ extract) and leonoside B (MW 784, $25.1 \pm 4.7 \mu \mathrm{g} / \mathrm{mg}$ extract) have been detected in L. cardiaca extracts. 
Table 2. Phenolic compounds of M. aquatica, L. dentata and L. cardiaca hydroethanolic extracts determined by UHPLC-DAD-ESI-MS ${ }^{n}$.

\begin{tabular}{|c|c|c|c|c|c|c|c|}
\hline \multicolumn{5}{|c|}{ - } & \multicolumn{3}{|c|}{ Plant Extract } \\
\hline \multirow[t]{2}{*}{ Peak } & $\underset{(\mathrm{min})}{\mathrm{RT}}$ & $\lambda \max (\mathrm{nm})$ & Compound & $\begin{array}{c}\text { ESI-MS } \\
\text { Fragmentation } \\
(m / z)\end{array}$ & \multicolumn{3}{|c|}{ Phenolic Content ( $\mu \mathrm{g} / \mathrm{mg}$ of extract) } \\
\hline & \multicolumn{7}{|c|}{ Caffeic acid derivatives } \\
\hline 1 & 8.2 & 290,329 & Caffeic acid glc & $341 \rightarrow 179 \rightarrow 135$ & - & - & $3.7 \pm 0.8$ \\
\hline 16 & 21.1 & 290,328 & Rosmarinic acid & $359 \rightarrow 179 \rightarrow 135,161$ & $64.2 \pm 8.8$ & $67.8 \pm 6.7$ & - \\
\hline \multicolumn{8}{|c|}{ Phenylethanoid glycosides } \\
\hline 5 & 16.7 & 290,329 & Lavandulifolioside & $755 \rightarrow 593 \rightarrow 461 \rightarrow 315$ & - & - & $253.6 \pm 35.8$ \\
\hline 7 & 17.5 & 290,329 & Verbascoside & $623 \rightarrow 461 \rightarrow 315 \rightarrow 135$ & - & - & $137.4 \pm 19.9$ \\
\hline 14 & 19.4 & ND & Leucoseptoside A & $637 \rightarrow 461 \rightarrow 315 \rightarrow 135$ & - & - & $31.5 \pm 4.6$ \\
\hline 15 & 20.0 & ND & Leonoside B & $783 \rightarrow 607 \rightarrow 475 \rightarrow 329$ & - & - & $25.1 \pm 4.7$ \\
\hline \multicolumn{8}{|c|}{ Flavones } \\
\hline 6 & 16.8 & $254,267,345$ & Luteolin-7-O-rut & $593 \rightarrow 285 \rightarrow 241$ & $43.3 \pm 10.0$ & - & - \\
\hline 10 & 18.1 & $253,267,345$ & Luteolin-7-O-glcA & $461 \rightarrow 285 \rightarrow 241$ & $\mathrm{D}$ & $26.2 \pm 4.0$ & - \\
\hline 12 & 18.9 & ND & Luteolin-7-O-rut & $593 \rightarrow 285 \rightarrow 257$ & - & - & $\mathrm{D}$ \\
\hline 17 & 21.1 & 266,329 & Apigenin-7-O-gl & $431 \rightarrow 269 \rightarrow 225$ & - & $\mathrm{D}$ & - \\
\hline 18 & 26.3 & 266,330 & $\begin{array}{l}\text { Apigenin-7-O-(6" } \\
\text { acetyl)glc }\end{array}$ & $473 \rightarrow 269,413$ & - & $\mathrm{D}$ & - \\
\hline \multicolumn{8}{|c|}{ Flavonols } \\
\hline 2 & 8.2 & ND & Rutin-O-glc & $771 \rightarrow 609 \rightarrow 301$ & - & $\mathrm{D}$ & - \\
\hline 3 & 13.7 & ND & Quercetin-3-O-soph & $625 \rightarrow 301 \rightarrow 179$ & - & - & $5.7 \pm 1.1$ \\
\hline 9 & 18.0 & $256,267,355$ & Rutin & $609 \rightarrow 301 \rightarrow 179$ & - & - & $15.8 \pm 2.1$ \\
\hline 11 & 18.9 & $256,267,357$ & Quercetin-3-O-glc & $463 \rightarrow 301 \rightarrow 179$ & - & - & $24.9 \pm 3.8$ \\
\hline \multicolumn{8}{|c|}{ Flavanones } \\
\hline 4 & 15.0 & $283,325 \mathrm{sh}$ & Eriodictyol-O-rut & $595 \rightarrow 287 \rightarrow 151 \rightarrow 107$ & $144.6 \pm 22.4$ & - & - \\
\hline 8 & 17.9 & $282,333 \mathrm{sh}$ & Naringenin-7-O-rut & $579 \rightarrow 271 \rightarrow 151$ & $24.4 \pm 3.7$ & - & - \\
\hline 13 & 19.5 & $283,325 \mathrm{sh}$ & Hesperetin-7-O-rut & $609 \rightarrow 301 \rightarrow 286 \rightarrow 241$ & $25.9 \pm 3.6$ & - & - \\
\hline
\end{tabular}

D, Detected; Glc, Glucoside; GlcA, Glucuronide; RT, retention time; Rut, Rutinoside; Soph, Sophoroside; Mean values \pm standard deviations; Numbers correspond to the UHPLC-DAD-ESI-MS ${ }^{n}$ peaks described in chromatograms in Figure 1. Supplementary Material S1.

Moreover, it must be highlighted that regardless of being the richest in total phenolic compounds, the L. cardiaca extract showed weak biological activity, both in the chemical and cellular models used here, thus indicating that their main phenolic compounds have low antioxidant and cytoprotective properties. In turn, the main phenolic components of M. aquatica or L. dentata extracts can in part be associated with the observed hepatoprotection due to antioxidant and additional mechanisms. Table 3 summarizes the Pearson correlation coefficients between the amounts of classes of phenolic components or major individual phenolic compounds found in the three hydroethanolic extracts and the results obtained in radical scavenging, 5-LOX inhibition assays and biological experiments. 
Table 3. Correlation coefficients between the amounts of phenolic components of M. aquatica, L. dentata and L. cardiaca hydroethanolic extracts and the data from the radical scavenging, 5-LOX inhibition assays and biological experiments.

\begin{tabular}{cccccc}
\hline Assay & Flavan & Flav & Flavo & PEG & RAc \\
\hline DPPH & 0.889 & 0.986 & -0.841 & -0.841 & 0.815 \\
RP & 0.973 & 0.917 & -0.688 & -0.688 & 0.653 \\
NO & 0.990 & 0.878 & -0.620 & -0.620 & 0.582 \\
ROS & 0.373 & 0.856 & -0.990 & -0.990 & 0.996 \\
CytP & 0.803 & 0.284 & 0.115 & 0.115 & -0.161 \\
\hline
\end{tabular}

Values expressed as Pearson Correlation Coefficient $R$; CytP-Cytoprotection (MTT 72h); PEG-Phenylethanoid glycosides; DPPH—DPPH radical scavenging activity; Flav—Flavones; Flavan-Flavanones; Flavo-Flavonols; NO-Nitric oxide radical scavenging capacity; $\mathrm{RP}$-reducing power potential; RAc-Rosmarinic Acid; ROS-Protection form ROS production $\left(25 \mu \mathrm{M} \mathrm{K}_{2} \mathrm{Cr}_{2} \mathrm{O}_{7}\right)$.

The most abundant hydroxycinnamic acid present in L. dentata and M. aquatica extracts, i.e., rosmarinic acid, was well correlated with the antioxidant effect measured by $\mathrm{DPPH}^{\bullet}(0.815)$ and ROS-scavenging protection in HepG2 cells (0.996). Indeed, rosmarinic acid has demonstrated to possess high scavenging ability via direct and indirect ROS-scavenging activities, including in the cell model herein used $[30,41,42]$. Additionally, rosmarinic acid is a strong scavenger of $\mathrm{ONOO}^{-}$and other free radicals $[3,43]$.

Concerning flavonoid compounds, the antioxidant effects measured by reducing power and for counteracting $\mathrm{DPPH}^{\bullet}$ and $\mathrm{NO}^{\bullet}$ showed to be in good agreement with the content of flavones and flavanones, with Pearson correlation coefficients of about 0.9. Of note, L. dentata and M. aquatica extracts contained moderate amounts of luteolin derivatives, and overall, the content of these flavones has a good correlation with almost all biological assays carried out in the present study. These data are consistent with the available literature, in which luteolin has been described as a cytoprotective agent in HepG2 and PC12 cells, in part due to its ROS scavenging activity [30,44].

The cytoprotective effect found in our assays was reasonably well correlated with the amounts of flavanones (0.803), which could explain the high activity of M. aquatica hydroethanolic extract, mainly composed of eriodictyol-7-O-rutinoside. In fact, it has been described that this compound has a lipoxygenase inhibitor action [45], and eriodictyol has been reported to reduce $\mathrm{NO}^{\bullet}$ production in macrophages [27,46]. Previous studies have also shown the efficacy of eriodictyol in ROS scavenging activity in HepG2 [30] and retinal cells [47]. In addition, a cytoprotective effect under similar conditions to these used in the present work has been reported [30]. Finally, M. aquatica hydroethanolic extract could exert effective protection through interference with proapoptotic events that lead to cell death, because eriodictyol is a potent inhibitor of key apoptotic steps, such as pro-caspase- 3 and pro-caspase- 9 cleavage and the release of cytochrome C [46,48].

\section{Conclusions}

The present study suggests the potential beneficial effect on liver cells of hydroethanolic extracts obtained from M. aquatica and L. dentata cultivated under an organic cultivation system. While M. aquatica extract exerts a cytoprotective effect on HepG2 cells, L. dentata extract has ROS-scavenging efficiency. Focusing on the phenolic profiles of the most-active extracts, their content in flavanones and in rosmarinic acid is possibly associated with the antioxidant and hepatoprotective effects of M. aquatica and L. dentata, respectively, and the extracts are proposed as valuable sources of natural metabolites with potential health-benefit properties.

Supplementary Materials: The following are available online at http://www.mdpi.com/2076-3921/8/8/267/s1, Figure S1: Chromatographic representation of Mentha aquatica (a), Lavandula dentata (b) (both at $280 \mathrm{~nm}$ ) and Leonurus cardiaca (c) (at $340 \mathrm{~nm}$ ) hydroethanolic extracts, Table S1: Linearity, LOD and LOQ of standard compounds used as references. 
Author Contributions: O.R.P. contribution to conceptualization, investigation, data curation, writing the original draft. R.I.R.M. and M.R.M.D. contribution to conceptualization, investigation, methodology and writing-review and editing. S.M.C. and J.J.G.M. contribution to conceptualization, investigation, methodology, supervision, and writing-review and editing.

Funding: Aveiro and FCT/MCT financed the QOPNA research Unit (FCT UID/QUI/00062/2019) through national funds and, where applicable, co-financed by the FEDER, within the PT2020 Partnership Agreement, to the Portuguese NMR Network and to the Portuguese Mass Spectrometry Network (RNEM, LISBOA-01-0145-FEDER-402-022125). This study was supported in part by the CIBERehd (EHD15PI05/2016) and Fondo de Investigaciones Sanitarias, Instituto de Salud Carlos III, Spain (PI16/00598, co-funded by European Regional Development Fund/European Social Fund, "Investing in your future"); Spanish Ministry of Economy, Industry and Competitiveness (SAF2016-75197-R); Junta de Castilla y Leon (SA063P17); AECC Scientific Foundation (2017/2020), Spain; and “Centro Internacional sobre el Envejecimiento" (OLD-HEPAMARKER, 0348_CIE_6_E), Spain. Project AgroForWealth (CENTRO-01-0145-FEDER-000001) funded by Centro2020, through FEDER and PT2020, financed the research contract of Susana M. Cardoso.

Conflicts of Interest: The authors declare no conflict of interest.

\section{References}

1. Marin, J.J.G.; Briz, O.; Herraez, E.; Lozano, E.; Asensio, M.; Di Giacomo, S.; Romero, M.R.; Osorio-Padilla, L.M.; Santos-Llamas, A.I.; Serrano, M.A.; et al. Molecular bases of the poor response of liver cancer to chemotherapy. Clin. Res. Hepatol. Gastroenterol. 2018, 42, 182-192. [CrossRef] [PubMed]

2. Hong, M.; Li, S.; Tan, H.Y.; Wang, N.; Tsao, S.; Feng, Y. Current Status of Herbal Medicines in Chronic Liver Disease Therapy: The Biological Effects, Molecular Targets and Future Prospects. Int. J. Mol. Sci. 2015, 16, 28705-28745. [CrossRef] [PubMed]

3. Li, S.; Tan, H.Y.; Wang, N.; Cheung, F.; Hong, M.; Feng, Y. The Potential and Action Mechanism of Polyphenols in the Treatment of Liver Diseases. Oxid. Med. Cell. Longev. 2018, 2018, 8394818. [CrossRef] [PubMed]

4. Catarino, M.D.; Alves-silva, J.M.; Pereira, O.R.; Cardoso, S.M. Antioxidant Capacities of Flavones and Benefits in Oxidative-Stress Related Diseases. Curr. Top. Med. Chem. 2015, 15, 105-119. [CrossRef] [PubMed]

5. Huo, X.; Liu, C.; Gao, L.; Xu, X.; Zhu, N.; Cao, L. Hepatoprotective Effect of Aqueous Extract from the Seeds of Orychophragmus violaceus against Liver Injury in Mice and HepG2 Cells. Int. J. Mol. Sci. 2017, 18, 1197. [CrossRef]

6. Stafford, G.I.; Pedersen, P.D.; Jäger, A.K.; Staden, J. Van Monoamine oxidase inhibition by southern African traditional medicinal plants. S. Afr. J. Bot. 2007, 73, 384-390. [CrossRef]

7. Conforti, F.; Sosa, S.; Marrelli, M.; Menichini, F.; Statti, G.A.; Uzunov, D.; Tubaro, A.; Menichini, F.; Loggia, R.D. In vivo anti-inflammatory and in vitro antioxidant activities of Mediterranean dietary plants. J. Ethnopharmacol. 2008, 116, 144-151. [CrossRef] [PubMed]

8. Olsen, H.T.; Stafford, G.I.; Van Staden, J.; Christensen, S.B.; Anna, K.J. Isolation of the MAO-inhibitor naringenin from Mentha aquatica L. J. Ethnopharmacol. 2008, 117, 500-502. [CrossRef]

9. Lis-Balchin, M. New research into Lavandula species, hybrids and cultivars. In Lavander The Genus Lavanda; Hardman, R., Ed.; Taylor \& Francis: London, UK, 2002; pp. 206-213.

10. Khalil, A.M.; Ashy, M.A.; Eltawil, B.A.H.; Tawfiq, N.I. Constituents of local plants. 5. Coumarin and triterpenoid constituents of Lavandula-dentata L plant. Pharmazie 1979, 34, 564-565.

11. Yang, Z.; Pan, S.; Huo, K.; Wu, B.; Chao, Z. Molecular Analysis of Leonurus Species in China Based on ITS and mat K Sequences. Am. J. Chin. Med. 2011, 39, 411-422. [CrossRef]

12. Ferhat, M.; Erol, E.; Beladjila, K.A.; Çetintaş, Y.; Duru, M.E.; Öztürk, M.; Kabouche, A.; Kabouche, Z. Antioxidant, anticholinesterase and antibacterial activities of Stachys guyoniana and Mentha aquatica. Pharm. Biol. 2017, 55, 324-329. [CrossRef] [PubMed]

13. López, V.; Akerreta, S.; Casanova, E.; García-mina, J.M.; Cavero, R.Y. In Vitro Antioxidant and Anti-rhizopus Activities of Lamiaceae Herbal Extracts. Plants Food Hum. Nutr. 2007, 62, 151-155. [CrossRef] [PubMed]

14. Benabdallah, A.; Rahmoune, C.; Boumendjel, M.; Aissi, O.; Messaoud, C. Total phenolic content and antioxidant activity of six wild Mentha species (Lamiaceae) from northeast of Algeria. Asian Pac. J. Trop. Biomed. 2016, 6, 760-766. [CrossRef]

15. Kosar, M.; Dorman, H.; Baser, K.; Filtunen, M. Screening of Free Radical Scavenging Compounds in Water Extracts of Mentha Samples Using a Postcolumn Derivatization. J. Agric. Food Chem. 2004, 52, 5004-5010. [CrossRef] [PubMed] 
16. Buchholz, T.; Melzig, M.F. Medicinal Plants Traditionally Used for Treatment of Obesity and Diabetes Mellitus-Screening for Pancreatic Lipase and $\alpha$-Amylase Inhibition. Phyther. Res. 2016, 30, 260-266. [CrossRef] [PubMed]

17. Sariri, R.; Seifzadeh, S.; Sajedi, R.H. Anti-tyrosinase and antioxidant activity of Lavandula sp. extracts. Pharmacol. Online 2009, 3, 319-326.

18. Algieri, F.; Rodriguez-Nogales, A.; Vezza, T.; Garrido-Mesa, J.; Garrido-Mesa, N.; Utrilla, M.P.; González-Tejero, M.R.; Casares-Porcel, M.; Molero-Mesa, J.; del Mar Contreras, M.; et al. Anti-inflammatory activity of hydroalcoholic extracts of Lavandula dentata L. and Lavandula stoechas L. J. Ethnopharmacol. 2016, 190, 142-158. [CrossRef] [PubMed]

19. Jafari, S.; Moradi, A.; Salaritabar, A.; Hadjiakhoondi, A.; Khanavi, M. Determination of total phenolic and flavonoid contents of Leonurus cardiaca. Res. J. Biol. Sci. 2010, 5, 484-487.

20. Sadowska, B.; Micota, B.; Rozalski, M.; Redzynia, M.; Rozalski, M. The immunomodulatory potential of Leonurus cardiaca extract in relation to endothelial cells and platelets. Innate Immun. 2017, 23, 285-295. [CrossRef]

21. López, V.; Martín, S.; Gómez-serranillos, M.P.; Carretero, M.E.; Jäger, A.K.; Calvo, M.I. Neuroprotective and Neurochemical Properties of Mint Extracts. Phytother. Res. 2010, 874, 869-874.

22. Conforti, F.; Ioele, G.; Statti, G.A.; Marrelli, M.; Ragno, G.; Menichini, F. Antiproliferative activity against human tumor cell lines and toxicity test on Mediterranean dietary plants. Food Chem. Toxicol. 2008, 46, 3325-3332. [CrossRef]

23. Flemmig, J.; Noetzel, I.; Arnhold, J.; Rauwald, H. Leonurus cardiaca L. herb extracts and their constituents promote lactoperoxidase activity. J. Funct. Foods 2015, 17, 328-339. [CrossRef]

24. Willer, H.; Schaack, D.; Lernoud, J. Organic Farming and Market Development in Europe and the European Union. In The World of Organic Agriculture-Statistics and Emerging Trends 2017; Organics International: Bonn, Germany, 2017.

25. American Herbal Products Association and Organic Trade Association. Guidance on Formulation and Marketing of Organic Dietary Supplements under the National Organic Program; AHPA: Silver Spring, MD, USA; QAI: San Diego, CA, USA; OTA: Washington, DC, USA, 2017.

26. Barański, M.; Średnicka-Tober, D.; Volakakis, N.; Seal, C.; Sanderson, R.; Stewart, G.B.; Benbrook, C.; Biavati, B.; Markellou, E.; Giotis, C.; et al. Higher antioxidant and lower cadmium concentrations and lower incidence of pesticide residues in organically grown crops: A systematic literature review and meta-analyses. Br. J. Nutr. 2014, 112, 794-811.

27. Afonso, A.F.; Pereira, O.R.; Válega, M.; Silva, A.M.S.; Cardoso, S.M. Metabolites and biological activities of Thymus zygis, Thymus pulegioides, and Thymus fragrantissimus grown under organic cultivation. Molecules 2018, 23, 1514. [CrossRef]

28. Pereira, O.R.; Domingues, M.R.M.; Silva, A.M.S.; Cardoso, S.M. Phenolic constituents of Lamium album: Focus on isoscutellarein derivatives. Food Res. Int. 2012, 48, 330-335. [CrossRef]

29. Catarino, M.D.; Silva, A.M.S.; Cruz, M.T.; Cardoso, S.M. Antioxidant and anti-inflammatory activities of Geranium robertianum L. decoctions. Food Funct. 2017, 8, 3355-3365. [CrossRef]

30. Pereira, O.R.; Macias, R.I.R.; Perez, M.J.; Marin, J.J.G.; Cardoso, S.M. Protective effects of phenolic constituents from Cytisus multiflorus, Lamium album L. and Thymus citriodorus on liver cells. J. Funct. Foods 2013, 5, 1170-1179. [CrossRef]

31. Afonso, A.F.; Pereira, O.R.; Neto, R.T.; Silva, A.M.S.; Cardoso, S.M. Health-promoting effects of Thymus herba-barona, Thymus pseudolanuginosus, and Thymus caespititius decoctions. Int. J. Mol. Sci. 2017, 18, 1879. [CrossRef]

32. Briz, O.; Serrano, M.A.; Macias, R.I.R.; Marin, J.J.G. Overcoming cisplatin resistance in vitro by a free and liposome-encapsulated bile acid derivative: Bamet-R2. Int. J. Cancer. 2000, 88, 287-292. [CrossRef]

33. Ebrahimzadeh, M.A.; Nabavi, S.F.; Nabavi, S.M.; Eslami, B.; Asgarirad, H. In vitro antioxidant and free radical scavenging activity of Leonurus cardiaca subsp. Persicus, Grammosciadium platycarpum and Onosma demawendicum. Afr. J. Biotechnol. 2010, 9, 8865-8871.

34. Matkowski, A.; Tasarz, P.; Szypuła, E. Antioxidant activity of herb extracts from five medicinal plants from Lamiaceae, subfamily Lamioideae. J. Med. Plant. Res. 2008, 2, 321-330. 
35. Sanchez-Vicente, L.; Herraez, E.; Briz, O.; Nogales, R.; Molina-Alcaide, E.; Marin, J.J.G. Biodetection of potential genotoxic pollutants entering the human food chain through ashes used in livestock diet. Food Chem. 2016, 205, 81-88. [CrossRef]

36. González, L.T.; Minsky, N.W.; Elsa, L.; Espinosa, M.; Aranda, R.S.; Meseguer, J.P.; Pérez, P.C. In vitro assessment of hepatoprotective agents against damage induced by acetaminophen and $\mathrm{CCl}_{4}$. BMC Complement. Altern. Med. 2017, 17, 1-10. [CrossRef]

37. Lee, J.; Yang, J.; Jeon, J.; Jeong, H.S.; Lee, J.; Sung, J. Hepatoprotective e ff ect of esculetin on ethanol-induced liver injury in human HepG2 cells and C57BL/6J mice. J. Funct. Foods 2018, 40, 536-543. [CrossRef]

38. Avila-Rojas, S.H.; Tapia, E.; Briones-Herrera, A.; Aparicio-Trejo, O.E.; León-Contreras, J.C.; Hernández-Pando, R.; Pedraza-Chaverri, J. Curcumin prevents potassium dichromate $\left(\mathrm{K}_{2} \mathrm{Cr}_{2} \mathrm{O}_{7}\right)$-induced renal hypoxia. Food Chem. Toxicol. 2018, 121, 472-482. [CrossRef]

39. Pereira, O.R.; Cardoso, S.M. Overview on Mentha and Thymus Polyphenols. Curr. Anal. Chem. 2013, 9, 382-396. [CrossRef]

40. Zhogova, A.A.; Perova, I.B.; Samylina, I.A.; Eller, K.I.; Ramenskaya, G.V. Identification and quantitative determination of the main biologically active substances in motherwort herb by HPLC—Mass Spectrometry. Pharm. Chem. J. 2014, 48, 461-466. [CrossRef]

41. Renzulli, C.; Galvano, F.; Pierdomenico, L.; Speroni, E.; Guerra, M.C. Effects of Rosmarinic Acid against Aflatoxin B 1 and Ochratoxin-A-induced Cell Damage in a Human Hepatoma Cell Line (Hep G2). J. Appl. Toxicol. 2004, 24, 289-296. [CrossRef]

42. Madushan, P.; Piao, M.J.; Kang, K.A.; Ryu, Y.S.; Hewage, S.R.; Chae, S.W.; Hyun, J.W. Rosmarinic Acid Attenuates Cell Damage against UVB Radiation-Induced Oxidative Stress via Enhancing Antioxidant Effects in Human HaCaT Cells. Biomol. Ther. 2016, 24, 75-84.

43. Liu, J.; Li, X.; Lin, J.; Li, Y.; Wang, T.; Jiang, Q.; Chen, D. Sarcandra glabra (Caoshanhu) protects mesenchymal stem cells from oxidative stress: A bioevaluation and mechanistic chemistry. BMC Complement. Altern. Med. 2016, 2016, 1-10. [CrossRef]

44. Lin, P.; Tian, X.; Yi, Y.S.; Jiang, W. Luteolin-induced protection of $\mathrm{H}_{2} \mathrm{O}_{2}$-Iinduced apoptosis in PC12 cells and the associated pathway. Mol. Med. Rep. 2015, 12, 7699-7704. [CrossRef]

45. Nogata, Y.; Ohta, H.; Ishii, T.; Sekiya, K. Isolation of eriocitrin (eriodictyol 7-O-rutinoside) as an arachidonate lipoxygenase inhibitor from Lumie fruit (Citrus lumia) and its distribution in Citrus species. J. Sci. Food Agric. 2007, 87, 82-89. [CrossRef]

46. Lee, J.K. Anti-inflammatory Effects of Eriodictyol in Lipopolysaccharide-stimulated Raw 264.7 Murine Macrophages. Arch. Pharm. Res. 2011, 34, 671-679. [CrossRef]

47. Miguel, F.; Rego, A.C.; Oliveira, C.R.; Maria, R. Antioxidant effect of flavonoids after ascorbate/Fe $\mathrm{Fe}^{2+}$-induced oxidative stress in cultured retinal cells. Biochem. Pharmacol. 2001, 62, 111-118.

48. Lou, H.; Jing, X.; Ren, D.; Wei, X.; Zhang, X. Neurochemistry International Eriodictyol protects against $\mathrm{H}_{2} \mathrm{O}_{2}$-induced neuron-like PC12 cell death through activation of Nrf2/ARE signaling pathway. Neurochem. Int. 2012, 61, 251-257. [CrossRef]

(C) 2019 by the authors. Licensee MDPI, Basel, Switzerland. This article is an open access article distributed under the terms and conditions of the Creative Commons Attribution (CC BY) license (http://creativecommons.org/licenses/by/4.0/). 